\title{
Advanced Natural Gas-Fired Turbine System Utilizing Thermochemical Recuperation and/or Partial Oxidation for Electricity Generation, Greenfield and Repowering Applications
}

Final Report March 1997
RECEIVED

AUG 111997

OSTI

Work Performed Under Contract No.: DE-FG21-95MC32071

For

U.S. Department of Energy

Office of Fossil Energy

Federal Energy Technology Center

Morgantown Site

P.O. Box 880

Morgantown, West Virginia 26507-0880

DHSTRABUTION OF THIS DOCUMENT IS UHH MUTED

By

Westinghouse Electric Corporation

Power Generation

4400 Alafaya Trail

Orlando, Florida 32826-2399 


\section{Disclaimer}

This report was prepared as an account of work sponsored by an agency of the United States Government. Neither the United States Government nor any agency thereof, nor any of their employees, makes any warranty, express or implied, or assumes any legal liability or responsibility for the accuracy, completeness, or usefulness of any information, apparatus, product, or process disclosed, or represents that its use would not infringe privately owned rights. Reference herein to any specific commercial product, process, or service by trade name, trademark, manufacturer, or otherwise does not necessarily constitute or imply its endorsement, recommendation, or favoring by the United States Govemment or any agency thereof. The views and opinions of authors expressed herein do not necessarily state or reflect those of the United States Government or any agency thereof. 


\section{DISCLAIMER}

Portions of this document may be illegible electronic image products. Images are produced from the best available original document. 


\section{TABLE OF CONTENTS}

LIST OF TABLES

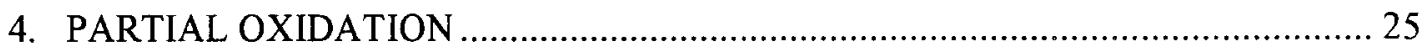

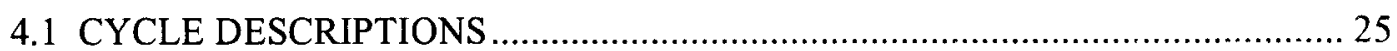

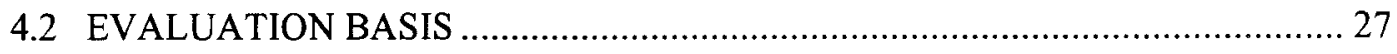

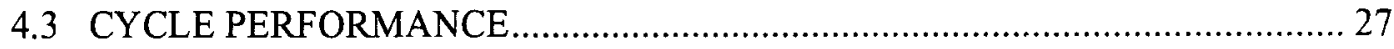

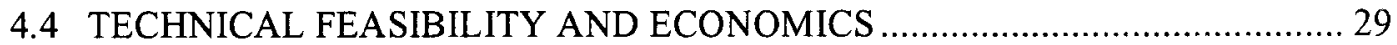

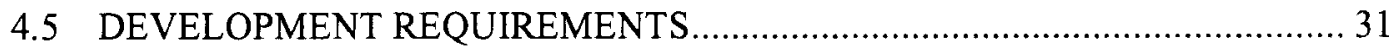

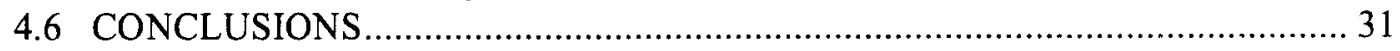

5. PARTIAL OXIDATION REPOWERING ...................................................... 33

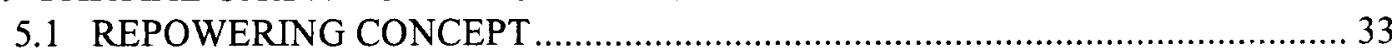

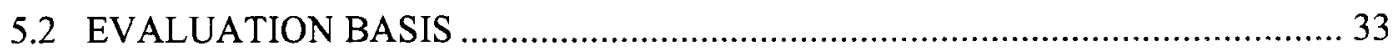

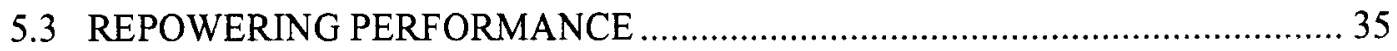

5.4 TECHNICAL FEASIBILITY AND DEVELOPMENT REQUIREMENTS .......... 36

5.5 REPOWERING CONCLUSIONS ........................................................... 37

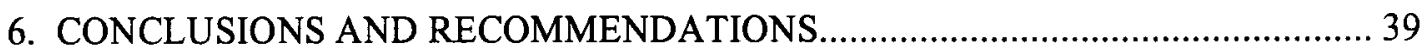

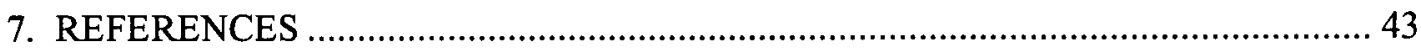




\section{LIST OF TABLES}

Number

Title

Page

$1 \quad$ Westinghouse Combustion Turbine Fleet..................................................... 5

2 Steam-TCR Performance Comparisons .................................................... 17

3 Flue Gas-TCR Performance Comparisons ....................................................... 19

4 Summary of Steam-TCR Results ............................................................ 20

$5 \quad$ Summary of Flue Gas-TCR Results ............................................................ 21

$6 \quad$ Performance of the Partial Oxidation Power Plant ............................................ 28

7 Conditions of Selected Gas Streams - 60 Bar PO Turbine Pressure.................... 29

8 Comparison of PO power Plant Economics with Conventional Power Plants..... 31

9 Selected Stream Conditions for Operating Pressure at 20.7 bar....................... 36

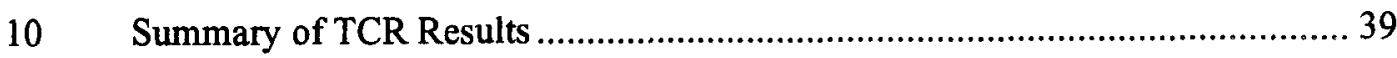

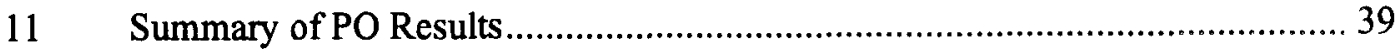




\section{LIST OF FIGURES}

Number

1

2

3

4

5
Title

Page

Steam-TCR Power Plant Cycle Diagram ......................................... 8

Steam Turbine Power Plant Cycle Diagram......................................... 9

Flue Gas-TCR Power Plant Cycle Diagram....................................... 13

PO Power Plant Cycle Diagram .................................................... 26

PO Turbine Repowering Diagram .................................................... 34 


\section{EXECUTIVE SUMMARY}

The performance, economics and technical feasibility of heavy duty combustion turbine power systems incorporating two advanced power generation schemes have been estimated to assess the potential merits of these advanced technologies. The advanced technologies considered were: Thermochemical Recuperation (TCR), and Partial Oxidation (PO). The performance and economics of these advanced cycles are compared to conventional combustion turbine SimpleCycles and Combined-Cycles. The objectives of the Westinghouse evaluation were to:

- simulate TCR and PO power plant cycles,

- evaluate TCR and PO cycle options and assess their performance potential and cost potential compared to conventional technologies,

- identify the required modifications to the combustion turbine and the conventional power cycle components to utilize the TCR and PO technologies,

- assess the technical feasibility of the TCR and PO cycles,

- identify what development activities are required to bring the TCR and PO technologies to commercial readiness.

Both advanced technologies involve the preprocessing of the turbine fuel to generate a lowthermal-value fuel gas, and neither technology requires advances in basic turbine technologies (e.g., combustion, airfoil materials, airfoil cooling). In TCR, the turbine fuel is reformed to a hydrogenrich fuel gas by catalytic contact with steam, or with flue gas (steam and carbon dioxide), and the turbine exhaust gas provides the indirect energy required to conduct the endothermic reforming reactions. This reforming process improves the recuperative energy recovery of the cycle, and the delivery of the low-thermal-value fuel gas to the combustors potentially reduces the $\mathrm{NO}_{\mathrm{x}}$ emission and increases the combustor stability.

The PO technology partially combusts the turbine fuel in a PO reactor, generating a lowthermal-value fuel gas. This fuel gas is expanded in a high-pressure turbine, the PO turbine, and the turbine exhaust gas is combusted as fuel for a second-stage, conventional heavy duty combustion turbine. The cycle reduces the relative amount of air requiring compression and increases the overall plant thermal efficiency. It is also expected to provide reduced $\mathrm{NO}_{\mathrm{x}}$ emissions.

Process simulation models of power systems based on the Westinghouse 501F combustion turbine (fueled by natural gas) were developed on ASPEN Plus ${ }^{\mathrm{TM}}$ to conduct the evaluations. Two TCR schemes were assessed, Steam-TCR and Flue Gas-TCR. Simple-Cycle versions of SteamTCR, Flue Gas-TCR and PO were simulated. A Combined-Cycle version of Flue Gas-TCR was 
also simulated. TCR and PO power plant efficiencies were estimated as a function of the major study parameters to determine acceptable cycle conditions. Cycle optimization was not performed. The cycle material and energy balance results were used to perform rough equipment sizing and to estimate power plant costs. A conventional coal-fired boiler repowering application was also considered, where the PO turbine exhaust gas functions as the conventional furnace fuel. Cost estimates were not generated for this repowering case and these evaluation looked only at the general feasibility of such a repowering scheme.

Compared to conventional combustion turbine power cycles, the two TCR schemes show the potential for some plant heat rate improvements, but their general technical and cost feasibilities are at issue. Both TCR schemes require the use of low sulfur natural gas to maintain reforming catalyst activity. The Steam-TCR scheme is the simplest and cheapest of the TCR cycles, and it has the highest technical feasibility. Steam-TCR has estimated power plant efficiencies more than 13 percentage points higher than the conventional Simple-Cycle power plant, and it also has considerably lower cost-of-electricity. On-the-other-hand, Steam-TCR has efficiency about 8 percent points lower than can be achieved with the conventional Combined-Cycle. Steam-TCR has capital investment and cost-of-electricity comparable to the conventional Combined-Cycle. High consumption of demineralized water may be an issue for Steam-TCR at some locations, but its technical issues and development requirements are moderate with respect to cost and time. Steam-TCR merits further evaluation for optimization of performance and cost.

The Combined-Cycle Flue Gas-TCR power plant efficiency is estimated to be only 0.3 percentage points greater than the efficiency of the conventional Combined-Cycle power plant, while the Simple-Cycle Flue gas-TCR power plant has estimated efficiency about 3 percentage points higher than the conventional Simple-Cycle. Flue Gas-TCR has capital investment and costof-electricity considerably higher than the conventional power plants. The complexity of the Flue Gas-TCR power plant is judged to be high, and extensive modifications are required to the combustion turbine and to other conventional power plant components. The development requirements for the Flue Gas-TCR power plant are great, with combustion performance and recycle flue gas cleaning requirements being key technology issues. Flue Gas-TCR development does not merit further consideration.

Simple-Cycle PO shows potential for efficiency improvements of more than 13 percentage points compared to the conventional Simple-Cycle, but is about 7 percentage points less efficient than the conventional Combined-Cycle. The Simple-Cycle PO power plant has cost-of-electricity 
considerably less than that of the conventional Simple-Cycle and comparable to the conventional Combined-Cycle. The Simple-Cycle PO power plant also has the potential to produce considerably more power than the conventional Simple-Cycle and Combined-Cycle power plants, but with several technical issues. The generation of soot in the PO reactor is a technical concern. Steam injection might control soot generation to acceptable levels. The development of the highpressure PO reactor and the PO turbine are major development requirements. The efficiency of the Simple-Cycle PO power plant is estimated to be slightly greater than that of the Steam-TCR power plant and has slightly better economics. Steam-TCR has large consumption of demineralized water while the PO power plant has lower, but still significant consumption of demineralized water. In general, PO merits further evaluation, and the cycle should be optimized.

The PO conventional boiler repowering scheme shows some interesting possibilities as a repowering technique. The PO turbine operates at more conventional pressure conditions when applied for repowering. Full replacement of the conventional boiler coal fuel by the clean turbine fuel was evaluated, but partial replacement of coal-firing is a more realistic situation. The conventional coal-fired, steam power plant efficiency can be increased significantly and its power output increased moderately with the PO retrofit scheme. The environmental performance of the conventional coal-fired power plant can also be improved by applying this repowering scheme, utilizing the $\mathrm{PO}$ turbine fuel for reburn $\mathrm{NO}_{\mathrm{x}}$ reduction. The evaluation performed here was only an exploratory consideration of the retrofit performance, and further evaluation to consider the practical aspects and performance of the boiler repowering adaptation to the PO fuel gas is needed.

Significant effort remains to develop, verify and commercialize both Steam-TCR and PO for combustion turbine power systems, with Steam-TCR being the technology closest to commercial readiness. Some alternative fuel types having lower reforming temperatures might be utilized in the Steam-TCR cycle more efficiently than can natural gas. Also, combustion turbines more advanced than the reference $501 \mathrm{~F}$ used in this evaluation (e.g., the 501G and ATS) will probably have greater efficiency and cost benefits from these advanced cycles. Both of these variations should be evaluated. 


\section{INTRODUCTION}

Numerous approaches for improving the thermal performance of combustion turbine power generation systems have been proposed since the early 1950s when combustion turbines were first applied for stationary power generation. Alternative approaches range from advanced topping and bottoming cycles, to advanced turbine firing conditions (Scalzo et al., 1996). Some of these approaches have been put into practice to reach the current level of performance that combustion turbine power generation has evolved to today. The prevalent factor enhancing performance has been increases in firing conditions (temperatures and pressures) through advances in airfoil design, materials and cooling methods (Bannister et al., 1995). The Westinghouse combustion turbine fleet is listed in Table 1 along with features such as firing conditions and cycle efficiency to illustrate this trend. The Westinghouse 501F combustion turbine is commercial, demonstrated technology. The $501 \mathrm{G}$ is state-of-the-art, combustion turbine technology to be demonstrated in 1997. The ATS combustion turbine is developing technology to be demonstrated in the year 2000 . Cycle variations are also being developed to improve system performance in contrast to hardware improvements, such as evaporative cooling cycles, recuperative cycles, intercooled cycles, humid air cycles, reheat cycles, advanced bottoming cycles, and elevated steam bottoming conditions (Briesch et al., 1995).

Table 1. Westinghouse Combustion Turbine Fleet

\begin{tabular}{|l|l|l|l|l|l|l|l|l|}
\hline & 501A & 501B & 501D & $501 \mathrm{D} 5$ & $501 \mathrm{DA}$ & $501 \mathrm{~F}$ & $501 \mathrm{G}$ & ATS \\
\hline Commercial year & 1968 & 1973 & 1976 & 1982 & 1994 & 1992 & 1997 & 2000 \\
\hline Power (Simple cycle), MWe & 45 & 80 & 95 & 107 & 120 & 160 & 230 & 290 \\
\hline Pressure ratio & 7.5 & 11.2 & 12.6 & 14.0 & 15.0 & 15.0 & 19.2 & 28.0 \\
\hline Rotor inlet temperature, ${ }^{\circ} \mathrm{C}\left({ }^{\circ} \mathrm{F}\right)$ & 879 & 993 & 1096 & 1132 & 1177 & 1277 & 1417 & 1510 \\
& $(1615)$ & $(1819)$ & $(2005)$ & $(2070)$ & $(2150)$ & $(2330)$ & $(2583)$ & $(2750)$ \\
\hline Exhaust temperature, ${ }^{\circ} \mathrm{C}\left({ }^{\circ} \mathrm{F}\right)$ & 474 & 486 & 513 & 527 & 540 & 584 & 593 & 593 \\
& $(885)$ & $(907)$ & $(956)$ & $(981)$ & $(1004)$ & $(1083)$ & $(1100)$ & $(1100)$ \\
\hline Efficiency - Simple (\%) & 27.1 & 29.4 & 31.2 & 34.0 & 34.5 & 35.5 & 38.5 & $-\cdots$ \\
\hline Efficiency - Combined (\%) & 37.9 & 46.4 & 46.9 & 48.4 & 48.6 & 53.1 & 58.0 & 60.0 \\
\hline
\end{tabular}

Many proposed approaches for advanced combustion turbine power cycles have been rejected as being unworkable or uneconomical, and some have not yet been developed sufficiently to be verified, demonstrated and commercialized. Thermochemical recuperation (TCR), also known as chemical recuperation, is one proposed technique that has been under evaluation for several years as a promising approach to increase power generation efficiencies, but it has not 
progressed to testing at a reasonable scale. Fuel reforming, the basis for the TCR cycle, is a commercial, mature technology in the chemical process industries, but its commercial operating conditions and process objectives are highly different for the power generation application. Several evaluations of the TCR technique applied to both heavy duty industrial turbines and aeroderivative turbines have been reported in the literature (Kesser et al., 1994; Ottarsson, 1991; Rao et al., 1993; Janes, 1990). These evaluations provide conflicting points of view on the effectiveness, feasibility, and practicality of TCR techniques.

Partial oxidation (PO) is another advanced technique proposed as a means to increase the performance of combustion turbine power systems based on theoretical, undemonstrated benefits. $\mathrm{PO}$ is a commercial process used in the process industries for generating syngases from hydrocarbons, again under conditions differing from those possible in power generation applications. A few evaluations of PO have appeared in the literature (Harvey et al., 1995; Walters and Weber, 1995), but assessment of its application to actual heavy duty industrial combustion turbines have not been reported.

In this evaluation, the potential incentives for developing these advanced cycles for use with heavy duty combustion turbines is assessed. The thermal performance potential of the power plant cycles is only one aspect of the evaluation. Technical feasibility and economic estimates are also required to make a judgment of the merits of the technologies. The evaluation estimates budgetary cost estimates that do not reflect commercial costs. 


\section{THERMOCHEMICAL RECUPERATION}

\subsection{TCR CYCLE DESCRIPTIONS}

Fuel reforming has been proposed by many organizations in the past as a means to improve the performance of combustion turbine power cycles, enhancing the performance of conventional thermal recuperation by incorporating endothermic fuel reforming reactions within the recuperator. Two alternative TCR cycle concepts are described and evaluated here for heavy duty industrial combustion turbine applications: Steam-TCR and Flue Gas-TCR. The scope of the evaluation considers the power plant thermal efficiency, economics and feasibility (technical issues, commercial component modifications required, development requirements, complexity, etc.).

\section{STEAM-TCR}

The Steam-TCR conceptual power cycle, a Simple-Cycle, is illustrated in Figure 1. The figure shows the exhaust gas from the combustion turbine passing through a thermochemical recuperator vessel. The turbine exhaust gas provides the thermal energy required to indirectly heat the countercurrently-flowing fuel-steam mixture and to simultaneously conduct endothermic fuel conversion reactions. The fuel-steam mixture flows through catalyst-filled tubes, while the turbine exhaust gas flows on the shell-side, countercurrent to the flow of the fuel-steam mixture. The partially-cooled turbine exhaust gas from the thermochemical recuperator vessel then passes through a heat recovery steam generator (HRSG) to produce steam. The general process flow diagram shows steam being generated both for reforming and for a steam-bottoming power plant. The Steam-TCR plant configuration considered in this evaluation has all of the steam generated being mixed with the turbine fuel for the steam-reformer reactions. This Steam-TCR cycle eliminates the steam turbine bottoming cycle used in conventional Combined-Cycle power plants, and is equivalent to a Simple-Cycle plant. A Combined-Cycle version of the Steam-TCR is also possible, if reforming with lower ratios of steam-to-fuel as acceptable.

The Steam-TCR cycle is comparable in many aspects to a Steam-Injected Turbine cycle, shown in Figure 2. The Steam-Injected Turbine cycle shown injects all of the steam generated in the HRSG into the combustor and turbine, resulting in lower $\mathrm{NO}_{\mathrm{x}}$ emission and more turbine power output through the increased turbine mass flow. The Steam-Injected Turbine cycle illustrated is of hypothetical value only, since this cycle is really applicable for use in cogeneration applications requiring process steam. In practice, not all of the steam potentially 


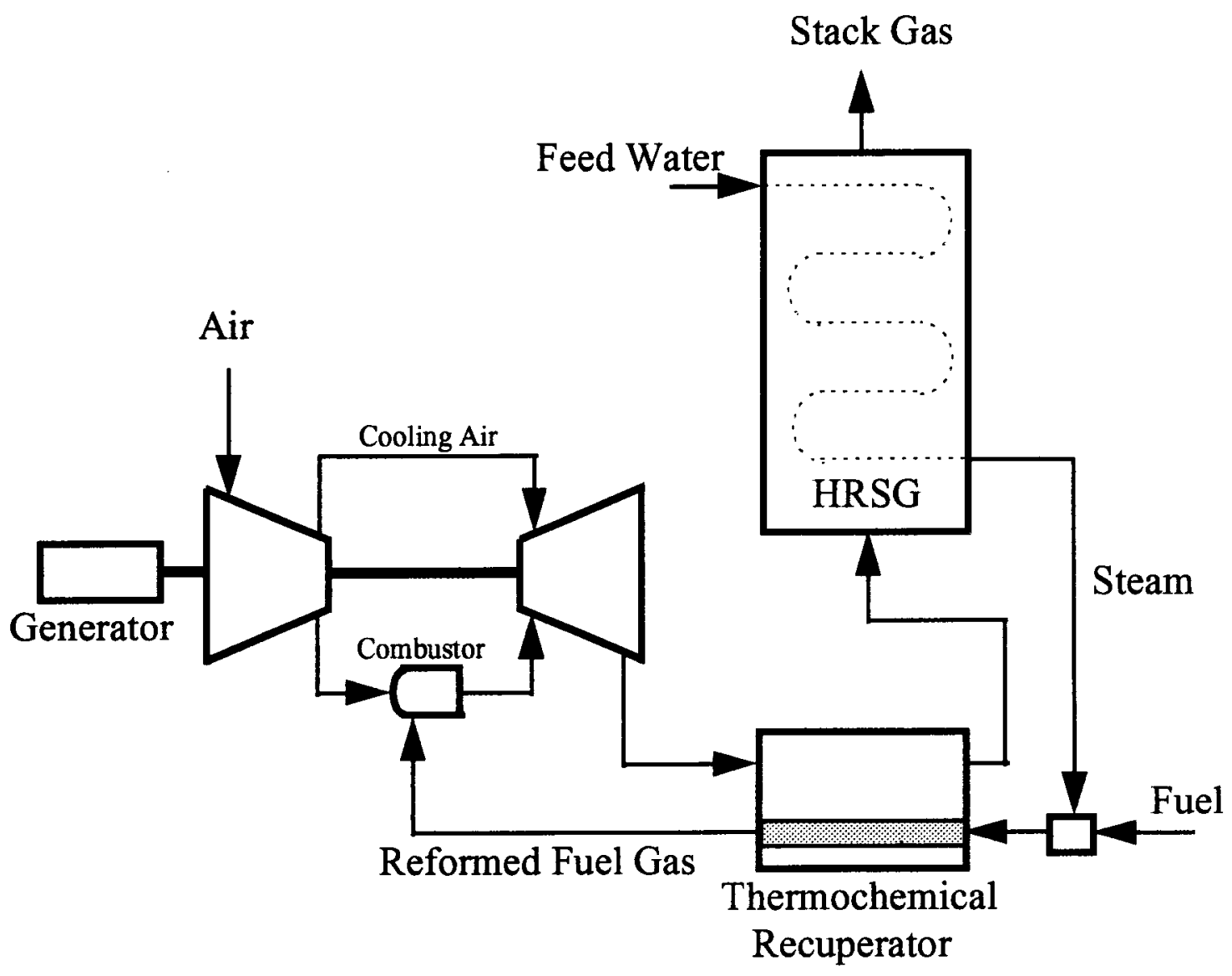

Figure 1. Steam-TCR Power Plant Cycle Diagram 


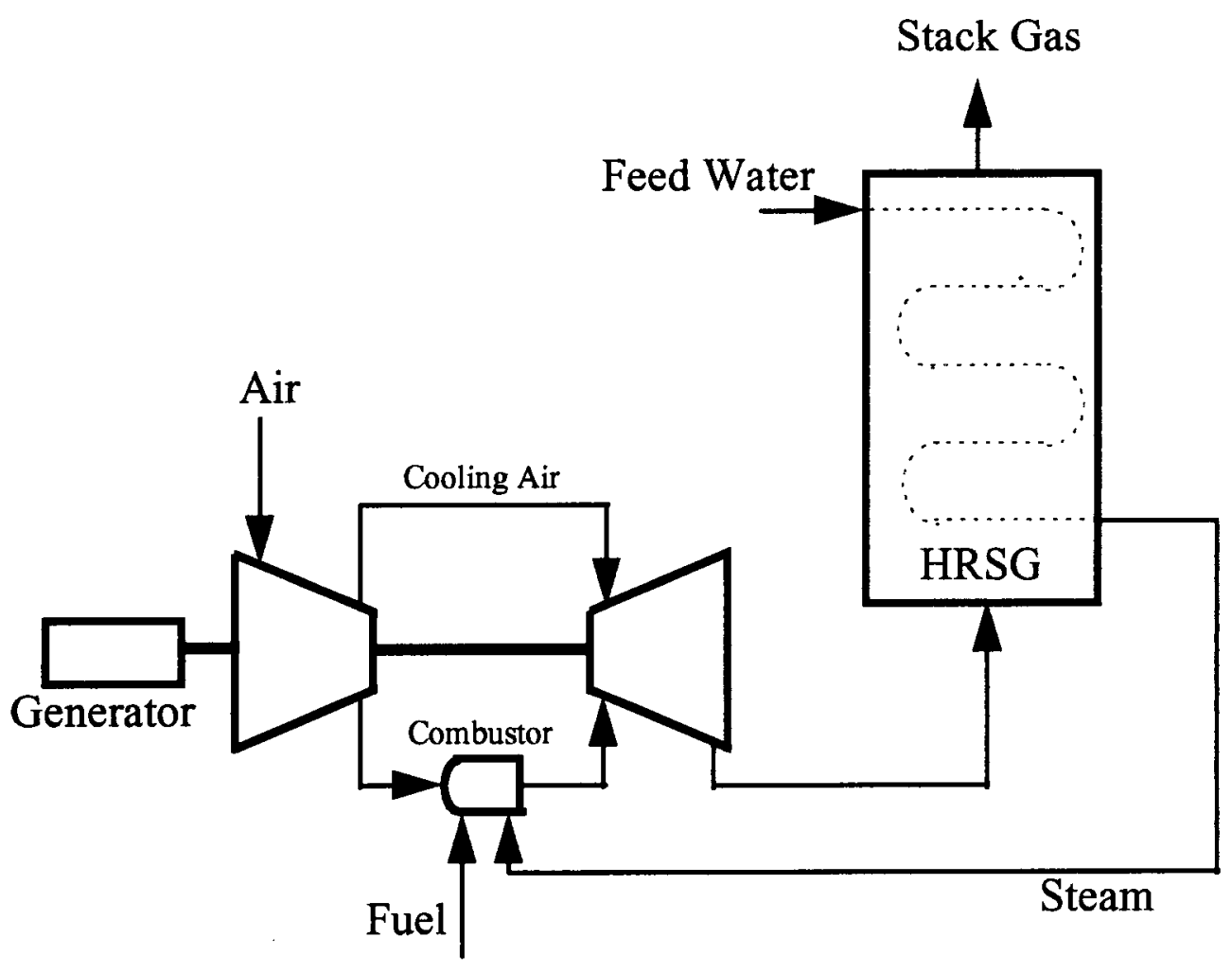

Figure 2. Steam-Injected Turbine Power Plant Cycle Diagram 
generated can be injected into the combustor or turbine due to limits on the steam-fuel mixture combustion stability and limits on the maximum turbine mass flow.

The major reactions involved in Steam-TCR are well known, and the overall reaction for a general hydrocarbon fuel, $\mathrm{C}_{\mathrm{n}} \mathrm{H}_{\mathrm{m}}$, is:

$$
\mathrm{C}_{\mathrm{n}} \mathrm{H}_{\mathrm{m}}+\mathrm{n} \mathrm{H}_{2} \mathrm{O} \Rightarrow>\mathrm{nCO}+(\mathrm{n}+\mathrm{m} / 2) \mathrm{H}_{2} \quad(\Delta \mathrm{H}=226 \mathrm{~kJ} / \text { mole for methane })
$$

Other reactions also enter into the reforming process, such as the water-shift reaction,

$$
\mathrm{CO}+\mathrm{H}_{2} \mathrm{O} \Leftrightarrow \mathrm{CO}_{2}+\mathrm{H}_{2} \quad(\Delta \mathrm{H}=41 \mathrm{~kJ} / \text { mole })
$$

and the Boudouard and methane decomposition reactions,

$$
\begin{array}{ll}
2 \mathrm{CO} \Leftrightarrow \mathrm{C}(\text { solid })+\mathrm{CO}_{2} . & (\Delta \mathrm{H}=-173 \mathrm{~kJ} / \text { mole }) \\
\mathrm{CH}_{4} \Leftrightarrow \mathrm{C}(\text { solid })+2 \mathrm{H}_{2} \quad(\Delta \mathrm{H}=75 \mathrm{~kJ} / \text { mole })
\end{array}
$$

The formation of carbon must be minimized in the operation of the reformer to minimize fouling of heat transfer surfaces, blinding of catalyst particles, plugging of flow paths and carbon losses.

The theoretical merits of the Steam-TCR concept are based on the overall endothermic nature of the reforming chemical reactions, and the formation of a low-thermal-value fuel gas replacing the high-thermal-value turbine fuel, with both factors contributing to improved efficiency in the power plant (Vakil, 1983; Rabovitser et al., 1996). The resulting low-thermal-value fuel gas may also have improved combustion stability characteristics compared to the fuel-steam mixture resulting in the Steam-Injected Turbine cycle. An added benefit of the hydrogen-rich, low-thermalvalue fuel gas is potentially lower $\mathrm{NO}_{\mathbf{x}}$ formation in the combustor.

The thermochemical recuperator vessel in Steam-TCR must be designed as an effective, economical catalytic reactor and heat exchanger, and several discussions of reformer design considerations have appeared in the literature (Janes, 1992; Rostrup-Nielsen et al., 1995). The high-pressure, steam-fuel mixture flows on the tube-side of the recuperator, with the tubes being filled with appropriately sized, nickel-based catalyst pellets. Turbine exhaust gas flows on the shell side, countercurrent to the steam-fuel mixture. The TCR vessel is usually pictured as being a component attached to the front of the HRSG.

The reforming of hydrocarbons catalytically with steam to generate hydrogen-rich syngas streams is a mature technology that is applied widely in the chemical process industries and in 
petroleum refining. In industrial chemical reforming applications, conditions are tailored for high fuel conversion efficiency using minimum steam-to-fuel ratios to maximize economic returns. In particular, in industrial applications the reforming reactions are performed at temperatures as high as about $900^{\circ} \mathrm{C}$ using high-temperature combustion products as the heat source in radiant furnace designs. While high fuel conversion is achieved, the high temperature catalyst exposure also results in relatively short catalyst life. These chemical processing temperatures are significantly higher than can be achieved in combustion turbine applications.

In combustion turbine applications, the fuel reforming reactions are limited by the reaction temperature that can be reached by heat exchange with the turbine exhaust gas, and the fuel conversion will only proceed to partial completion. The firing of the Steam-TCR vessel has been proposed in the past as a means to achieve higher fuel reformation conversions (Horner and Hines, 1990), but this approach is not utilized in this evaluation. In combustion turbine applications, the steam-to-fuel ratio is higher than used in industrial applications, and the operating pressure is lower, so the conversion of fuel is still significant. Also, the steam-to-fuel ratios are large enough that carbon formation is not expected (Janes, 1992; Rostrup-Nielsen et al., 1995).

The sensitivity of nickel-based catalysts to sulfur species requires that the fuel be desulfurized to very low sulfur levels, using commercial zinc-based sorbent or activated carbon contacting methods. The low temperature exposure of the catalyst in combustion turbine applications should result in relatively long catalyst life compared to industrial practice. The nickel-based catalysts used for fuel reforming become active at temperatures greater than $300^{\circ} \mathrm{C}$, temperatures that can be achieved in combustion turbine applications, and above this temperature the fuel conversion approaches equilibrium behavior in properly designed reactors (Janes, 1992; Rostrup-Nielsen et al., 1995).

\section{FLUE GAS-TCR}

Flue Gas-TCR is an alternative fuel reforming power cycle. The Flue Gas-TCR cycle utilizes recycled flue gas, rather than steam, as the reactant for the reforming reactions, and with this a Combined-Cycle configuration can be maintained. The fuel conversion reactions involve partial combustion resulting from the flue gas excess oxygen content, as well as steam reforming and carbon dioxide reforming:

$$
\begin{array}{ll}
\mathrm{C}_{\mathrm{n}} \mathrm{H}_{\mathrm{m}}+\mathrm{n} / 2 \mathrm{O}_{2} \Rightarrow \mathrm{n} \mathrm{CO}+\mathrm{m} / 2 \mathrm{H}_{2} \quad(\Delta \mathrm{H}=-44 \mathrm{~kJ} / \mathrm{mole} \text { for methane }) \\
\mathrm{C}_{\mathrm{n}} \mathrm{H}_{\mathrm{m}}+\mathrm{n} \mathrm{CO}_{2}=>2 \mathrm{n} \mathrm{CO}+\mathrm{m} / 2 \mathrm{H}_{2} \quad(\Delta \mathrm{H}=261 \mathrm{~kJ} / \text { mole for methane })
\end{array}
$$




$$
\mathrm{C}_{\mathrm{n}} \mathrm{H}_{\mathrm{m}}+\mathrm{n} \mathrm{H}_{2} \mathrm{O}=>\mathrm{n} \mathrm{CO}+(\mathrm{n}+\mathrm{m} / 2) \mathrm{H}_{2} \quad(\Delta \mathrm{H}=226 \mathrm{~kJ} / \text { mole for methane }
$$

The water shift reaction and the Boudouard reaction may be significant under some process conditions. Again, the fuel reforming is a highly endothermic process, if the flue gas oxygen content is sufficiently low, and the process benefits the overall cycle efficiency as it does in SteamTCR.

A Flue Gas-TCR cycle concept is illustrated in Figure 3. Versions of this have been described in the literature (Harvey et al., 1995; Rabovitser et al., 1996). In this process, flue gas is recycled from a point before the stack and is used both for fuel reforming and for turbine airfoil cooling. Because of the presence of excess oxygen in the turbine exhaust gas, the cycle must be arranged so that the excess oxygen level in the flue gas is small (about 1 to $2 \%$ oxygen by volume). The recycled flue gas is cooled indirectly by inlet air so that it can be efficiently compressed in an intercooled flue gas compressor. Part of the compressed flue gas is distributed to the turbine expander for airfoil cooling. The remainder of the compressed flue gas is mixed with turbine fuel within the thermochemical recuperator vessel, raising the temperature of the mixture slightly by partial combustion before the mixture enters the catalytic conversion and heat exchanger sections of the thermochemical recuperator. As is shown in Figure 3, a portion of the recycle flue gas may also be circulated directly to the turbine combustor. The low-thermal-value reformed fuel gas is sent to the turbine combustor where combustion is completed using compressed air, and the combustion products are expanded. Turbine exhaust gas is first partially cooled as it passes through the thermochemical recuperator. The turbine exhaust is then used to raise steam for a steam bottoming cycle.

In this cycle, the design of the thermochemical recuperator incorporates an initial partial oxidation section followed by heat exchange and catalytic reactor sections. Noble metal or nickelbased catalysts may be used, and it is likely that fuel desulfurization will be required to reduce catalyst deactivation. The gas chemistry is such that carbon formation will not occur in the reactor. The recuperation temperatures and fuel conversions achieved may be slightly higher than those in the Steam-TCR cycle. 


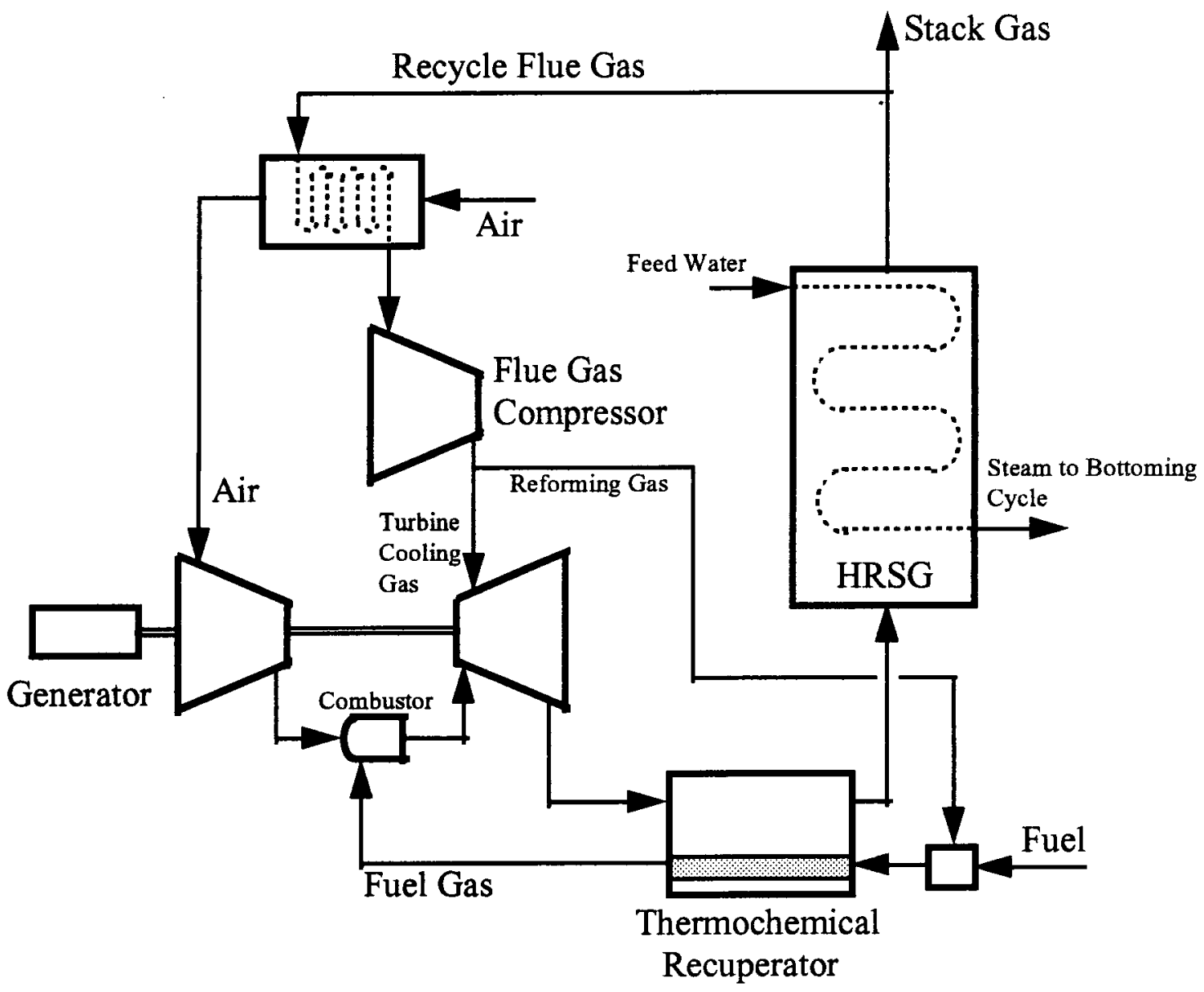

Figure 3. Flue Gas-TCR Power Plant Cycle Diagram 


\subsection{EVALUATION BASIS}

Power plant process calculations and economic estimates have been made for a specific heavy duty industrial combustion turbine, turbine fuel, and set of performance assumptions and costing premises. Steam-TCR and Fuel Gas-TCR have been evaluated with the following technical basis:

- Turbine: Westinghouse 501F heavy duty industrial combustion turbine

- Fuel: desulfurized natural gas (modeled as pure methane)

- Conditions: ISO, base load

- Turbine mass flow maintain at the $501 \mathrm{~F}$ design mass flow

- Rotor inlet temperature maintained at the 501F design rotor inlet temperature

- Reforming reaction conversion performance estimated by three methods:

* equilibrium conversion,

* IGT partial conversion correlations,

* partial conversion based on prior literature correlations (Kesser, et al., 1994)

- TCR vessel outlet temperature approach: $20^{\circ} \mathrm{C}$

- TCR vessel, control valve fuel-side pressure drop: $2.0 \mathrm{bar}$

The TCR process and cycle conditions were not optimized in the evaluation, but typical approach temperatures for the TCR reactor were selected and applied with only limited variation. Standard assumptions used in Westinghouse commercial cycle estimates for power island component heat losses, pressure drops, mechanical losses, efficiency factors and auxiliary losses have been applied.

The $501 \mathrm{~F}$ engine is a 3600 -rpm heavy duty industrial combustion turbine designed to serve the $60-\mathrm{Hz}$ power generation needs. The $701 \mathrm{~F}$ is a $220 \mathrm{MWe}$-class heavy duty gas turbine for $50-\mathrm{Hz}$ markets. Some major $501 \mathrm{~F}$ characteristics based on natural gas fuel are:

- Air flow, $\mathrm{kg} / \mathrm{s}(\mathrm{lb} / \mathrm{s})$ : $436(961)$

- Number of compressor stages: 16

- Compression ratio: 14.6

- Number of combustor cans: 16

- Turbine exhaust gas flow, $\mathrm{kg} / \mathrm{s}(\mathrm{lb} / \mathrm{s}): \quad 445(981)$

- Rotor inlet temperature, ${ }^{\circ} \mathrm{C}\left({ }^{\circ} \mathrm{F}\right)$ : $1316(2400)$

- Exhaust temperature, ${ }^{\circ} \mathrm{C}\left({ }^{\circ} \mathrm{F}\right)$ : 607 (1125)

- Number of turbine stages: 4

- Number of cooled turbine rows: 6

To date, 60 of the $501 \mathrm{~F} / 701 \mathrm{~F}$ machines have been sold, and the 22 units currently operating have accumulated a combined 215,000 operating hours. The longest operating 501Fs are located 
at the FP\&L, Lauderdale plant. The 4 units at this site have compiled more than 120,000 hours of operation with an average availability of over $94 \%$.

The process flow diagrams have been evaluated using the ASPEN Plus ${ }^{\mathrm{TM}}$ process simulator which is well adapted to handling power cycles with nonstandard chemical conversions. A detailed stage-by-stage model of the $501 \mathrm{~F}$ was incorporated into the process simulator. The thermochemical recuperator was modeled as a countercurrent heat exchanger. Detailed designs were not conducted on the reformer, looking only at its thermodynamic potential and rough sizing.

With appropriate catalysts and operating conditions the methane reforming reactions are expected to proceed almost the equilibrium. Experimental correlations for methane reforming conversion in steam and steam-carbon dioxide mixtures have been developed by the Institute of Gas Technology (IGT) based on recent information collected from the former USSR, and these confirm a close approach to equilibrium. A recent paper (Kesser et al., 1994) reported an estimation technique for the chemical equilibrium temperature-approach:

$$
\begin{aligned}
& \Delta \mathrm{T}_{\text {eq }}=0 \text { for } \mathrm{T}_{\mathrm{r}}>650^{\circ} \mathrm{C} \\
& \Delta \mathrm{T}_{\text {eq }}=43.33 \times\left(1.0-\mathrm{T}_{\mathrm{r}} / 650\right) \text { for } \mathrm{T}_{\mathrm{r}}<650^{\circ} \mathrm{C}
\end{aligned}
$$

where $\Delta \mathrm{T}_{\text {eq }}$ is the chemical equilibrium temperature-approach, and $\mathrm{T}_{\mathrm{r}}$ is the reformer operating temperature.

The Steam-TCR and Flue Gas-TCR cycle results have been assessed with respect to the performance merits of the TCR cycles as well as with regard to their economics, impact on required combustion turbine modifications, and the general feasibility of the cycles.

The economic premises applied were:

- Cost year: 2000

- General inflation rate: $4 \%$

- Construction period: 12 months

- Construction period interest rate: $8 \%$

- Plant boundary: power island and major auxiliaries for turnkey plant

- Fuel cost: $\$ 3.00 / \mathrm{MMBtu}$

- Capacity factor: $85 \%$

- Capacity degradation: $2 \% / y r$

- Heat rate degradation: $2 \% / y r$

- Other financial premises consistent with Westinghouse commercial sales 
Equipment costs for non-standard components, such as the TCR reactors, were order-ofmagnitude estimates based on general cost correlations and cost data for similar equipment. Standard component equipment costs were taken from recent quotes and scaled as needed.

\subsection{STEAM-TCR CYCLE PERFORMANCE}

In the Steam-TCR power plant, the turbine exhaust gas is cooled from its $600^{\circ} \mathrm{C}$ initial temperature to about $427^{\circ} \mathrm{C}$ in the thermochemical recuperator, before the exhaust gas is used to raise steam at $207^{\circ} \mathrm{C}$ and 21.6 bar pressure. Two major performance factors in the Steam-TCR cycle are the reformed fuel gas temperature achieved and the natural gas conversion that results. In the Steam-TCR cycle studied, the values achieved were estimated as:

- $\quad$ reformed fuel temperature $\left({ }^{\circ} \mathrm{C}\right): \quad 579$

- natural gas reformer conversion (\%): 38

The approach temperature to equilibrium is estimated to be about $5^{\circ} \mathrm{C}$, and an assumption of equilibrium conversion would have a very small influence on the conversion and the plant efficiency. Even with a $38 \%$ level of fuel conversion, the benefits of thermochemical recuperation are evident in the results shown below. The low-thermal-value fuel gas composition (volume percent) is estimated as:

$\begin{array}{lr}\mathrm{CO}: & 0.18 \\ \mathrm{CO}_{2}: & 3.59 \\ \mathrm{H}_{2} \mathrm{O}: & 71.78 \\ \mathrm{H}_{2}: & 14.90 \\ \mathrm{CH}_{4}: & 9.55\end{array}$

with an average molecular weight of 16.4 and a hot-gas heating value (LHV) of about $7.9 \mathrm{MJ} / \mathrm{kg}$ (3400 Btu/lb) or about $3.5 \mathrm{MJ} / \mathrm{nm}^{3}(94 \mathrm{Btu} / \mathrm{scf})$.

The main process parameters of interest to the Steam-TCR cycle performance, listed in Table 2, are compared to the performance of the conventional Simple-Cycle and the conventional Combined-Cycle. The efficiency of the Steam-TCR plant, significantly less thian that of the conventional Combined-Cycle plant ( 8.1 percentage points less), is substantially higher than that of the conventional Simple-Cycle plant (13 percentage points higher). The water consumption rate is much higher than in the conventional Combined-Cycle or Simple-Cycle plants. The net power generated by the Steam-TCR plant is intermediate to the Combined-Cycle and Simple-Cycle plants. 
Table 2. Steam-TCR Performance Comparisons

\begin{tabular}{|l|c|c|c|}
\hline & Steam-TCR & $\begin{array}{l}\text { Conventional } \\
\text { Simple-Cycle }\end{array}$ & $\begin{array}{l}\text { Conventional } \\
\text { Combined-Cycle }\end{array}$ \\
\hline $\begin{array}{l}\text { steam-to-natural gas } \\
\text { ratio (mass): }\end{array}$ & 6.6 & NA & NA \\
\hline $\begin{array}{l}\text { air-to-natural gas ratio } \\
\text { (mass): }\end{array}$ & 43.0 & 42.7 & 42.7 \\
\hline $\begin{array}{l}\text { makeup water rate } \\
\text { (kg/kWh): }\end{array}$ & 1.0 & 0 & 0.02 \\
\hline $\begin{array}{l}\text { stack gas temperature } \\
\left({ }^{\circ} \mathrm{C}\right):\end{array}$ & 126 & 590 & 129 \\
\hline $\begin{array}{l}\text { Net cycle power } \\
(\mathrm{MWe}):\end{array}$ & 216 & 166 & 264 \\
\hline $\begin{array}{l}\text { Net cycle efficiency }(\% \\
\text { LHV): }\end{array}$ & 48.9 & 35.7 & 56.8 \\
\hline
\end{tabular}

At the selected thermochemical reformer conditions with steam-to-fuel mass ratio of about 6.6 , carbon formation is expected to be negligible in the reforming reactor. It is also expected that the hot, low-thermal-value fuel gas combustibility will be excellent based on Westinghouse combustion experience with similar fuel gases. This evaluation has considered the steam reforming of natural gas. The Steam-TCR power plant performance with other fuels having lower reforming temperatures should be better than the natural gas case considered (Rostrup-Nielsen, et al., 1995). The Steam-TCR cycle is expected to have at least the same relative performance benefits for the advanced Westinghouse $501 \mathrm{G}$ and ATS turbine conditions that it has for the 501F turbine.

\subsection{FLUE GAS-TCR CYCLE PERFORMANCE}

Both Simple-Cycle and Combined-Cycle versions of Flue Gas-TCR have been evaluated. In the Flue Gas-TCR power plant, the thermochemical recuperator cools the turbine exhaust gas to about $490^{\circ} \mathrm{C}$ before the exhaust gas is used to raise steam for the steam bottoming cycle. Two major performance factors in the Flue Gas-TCR cycle are the reformed fuel gas temperature achieved and the natural gas conversion that results. In the Flue Gas-TCR cycle studied, the values achieved were estimated as:

- $\quad$ reformed fuel exit temperature $\left({ }^{\circ} \mathrm{C}\right): \quad 597$

- fuel reformer conversion (\%): 56

In this cycle, the air consumption rate is only about $37 \%$ of what it is in the Steam-TCR cycle, with recycled flue gas providing the remaining oxidant and cooling requirements. The total 
stack gas rate is about $35 \%$ of the stack gas rate in the Steam-TCR power plant. The flue gas recycle-to-natural gas mass ratio is about 32.3 in the Flue Gas-TCR power plant, and the combustor outlet excess oxygen content is only about $1 \%$ by volume. Under conditions of complete circulation of recycle flue gas to the flue gas-TCR vessel, the low-thermal-value fuel gas composition (volume percent) is estimated as:

$\begin{array}{lr}\mathrm{CO}: & 1.74 \\ \mathrm{CO}_{2}: & 9.13 \\ \mathrm{H}_{2} \mathrm{O}: & 15.07 \\ \mathrm{H}_{2}: & 7.44 \\ \mathrm{CH}_{4}: & 2.13 \\ \mathrm{~N}_{2}: & 64.49\end{array}$

with an average molecular weight of 25.8 and a hot-gas heating value (LHV) of about $2.1 \mathrm{MJ} / \mathrm{kg}$ $(920 \mathrm{Btu} / \mathrm{lb})$ or about $1.1 \mathrm{MJ} / \mathrm{nm}^{3}$ (30 Btu/scf). This very low fuel gas thermal value is similar to some blast furnace fuel gases, and since it is warm gas $\left(579^{\circ} \mathrm{C}\right)$ it could probably be combusted with acceptable efficiency. It is possible to increase the fuel gas thermal value simply by bypassing a portion of the recycled flue gas around the thermochemical recuperator and directly into the turbine combustors, injecting the flue gas at the combustor quench zone. Bypassing may be needed to ensure that efficiency fuel gas combustion can be performed. Bypassing recycle flue gas has a small impact on the power plant efficiency.

Other process parameters of interest to the Flue Gas-TCR power plant performance are listed in Table 3 and are compared to the performance of the conventional Simple-Cycle, and the Combined-Cycle power plants. The Simple-Cycle and Combined-Cycle versions of Flue Gas-TCR are only slightly more efficient than the conventional Simple-Cycle and Combined-Cycle power plants, respectively: 3 percent points higher for Simple-Cycle Flue Gas-TCR and 0.3 percentage points higher for Combined-Cycle Flue Gas-TCR. Flue Gas-TCR results in much less consumption of demineralized water than is needed for Steam-TCR.

At the selected thermochemical reformer conditions, carbon formation should be negligible in the reactor. It is also expected that the hot, very low-thermal-value fuel gas combustibility will be acceptable, but the low excess oxygen content of the combustion products may result in high carbon monoxide production. Flue gas bypass of the thermochemical recuperator may be needed to increase the fuel gas thermal value. 
Table 3. Flue Gas-TCR Performance Comparisons

\begin{tabular}{|l|c|c|c|c|}
\hline & $\begin{array}{l}\text { Flue Gas-TCR } \\
\text { Simple Cycle }\end{array}$ & $\begin{array}{l}\text { Flue Gas-TCR } \\
\text { Combined }\end{array}$ & $\begin{array}{l}\text { Conventional } \\
\text { Simple-Cycle }\end{array}$ & $\begin{array}{l}\text { Conventional } \\
\text { Combined-Cycle }\end{array}$ \\
\hline $\begin{array}{l}\text { recycle flue gas-to-air } \\
\text { ratio (mass): }\end{array}$ & 2.0 & 2.0 & 0 & 0 \\
\hline $\begin{array}{l}\text { air-to-natural gas ratio } \\
\text { (mass): }\end{array}$ & 18.1 & 18.1 & 42.7 & 42.7 \\
\hline $\begin{array}{l}\text { makeup water rate } \\
\text { (kg/kWh): }\end{array}$ & 0 & 0.01 & 0 & 0.02 \\
\hline $\begin{array}{l}\text { stack gas temperature } \\
\left({ }^{\circ} \mathrm{C}\right):\end{array}$ & 433 & 93 & 590 & 129 \\
\hline $\begin{array}{l}\text { Net cycle power } \\
(\mathrm{MWe}):\end{array}$ & 181 & 228 & 166 & 264 \\
\hline $\begin{array}{l}\text { Net cycle efficiency }(\% \\
\text { LHV): }\end{array}$ & 38.7 & 57.1 & 35.7 & 56.8 \\
\hline
\end{tabular}

\subsection{TECHNICAL FEASIBILITY AND ECONOMICS}

The thermal performance potential of the power plant cycles is only one aspect of the evaluation. Technical feasibility and economic estimates are also required to make a judgment of the merits of the technologies.

\section{STEAM-TCR}

The major components in the Steam-TCR cycle are the air compressor system, the combustors, the turbine expander, the HRSG, and the thermochemical recuperator. Technically, the Steam-TCR process is relatively simple and requires only limited modifications to the power plant commercial equipment. Technical issues relate to many aspects of the Steam-TCR reactor design and operation, and some information on this has been reported in the literature (Adelman et al., 1995). Primarily, the design and operating parameters for the thermochemical recuperator should be varied to optimize the vessel size, heat transfer surface area, volume of catalyst contained in the vessel, catalyst loss rate, gas pressure drop, and equipment cost and operating cost. Utilization of the Steam-TCR cycle has several minor impacts on the combustion turbine and requires a number of modifications to the normal combined-cycle equipment and configuration. Turbine and compressor modifications required to use Steam-TCR are similar to those made to accommodate integrated gasification combined cycle process conditions in combustion turbine power plants and are well understood modifications:

- only slight reduction in compressor air rate

- combustor modifications for combustion of hot, low-thermal-value fuel gas 
- elimination of the steam bottoming cycle

- modifications to the HRSG

- modifications to the power plant control system

The modifications required are also similar to those made if the Steam-Injected Turbine cycle were to be used.

A comparison of cost of the Steam-TCR power plant and the conventional Simple-Cycle and Combined-Cycles power plant costs are listed in Table 4, showing estimates of capital cost and cost-of-electricity. The Steam-TCR cycle is estimated to have economic potential greater

Table 4. Summary of Steam-TCR Results

\begin{tabular}{|l|c|c|c|c|l|}
\hline & $\begin{array}{c}\text { Capacity } \\
(\mathrm{MWe})\end{array}$ & $\begin{array}{c}\text { Efficiency } \\
(\%, \mathrm{LHV})\end{array}$ & $\begin{array}{c}\text { Capital Cost } \\
(\$ / \mathrm{kW})\end{array}$ & $\begin{array}{c}\text { COE } \\
(\mathrm{cents} / \mathrm{kWh})\end{array}$ & \multicolumn{1}{c|}{$\begin{array}{c}\text { Practicality } \\
\text { Issues }\end{array}$} \\
\hline Steam-TCR & 216 & 48.9 & 339 & 3.7 & $\begin{array}{l}\text { - Large water consumption } \\
\text { - Desulfurized fuel needed } \\
\text { - TCR vessel design }\end{array}$ \\
\hline $\begin{array}{l}\text { Conv. Simple- } \\
\text { Cycle }\end{array}$ & 166 & 35.7 & 276 & 4.6 & $\bullet$ Commercial \\
\hline $\begin{array}{l}\text { Conv. Combined- } \\
\text { Cycle }\end{array}$ & 264 & 56.8 & 410 & 3.5 & $\bullet$ Commercial \\
\hline
\end{tabular}

than the conventional Simple-Cycle power plant and comparable to the conventional CombinedCycle power plant. It is expected that further evaluation can optimize the Steam-TCR performance and economics to improve the potential of the Steam-TCR cycle even further.

\section{FLUE GAS-TCR}

The major components in the Flue Gas-TCR power plant are the air compressor system, the flue gas recycle system, the combustors, the turbine expander, the HRSG, and the thermochemical recuperator. The turbine airfoils are cooled by recycled flue gas in this cycle so that the turbine exhaust gas oxygen content can be maintained at a low level.

Flue Gas-TCR produces power plant efficiencies only slightly higher than those of the conventional Combined-Cycle plant, and requires major modifications to the combustion turbine equipment and adds major additional equipment and complexity to the power plant. The combustion turbine air compressor is greatly reduced in capacity, the compressor air inlet temperature is increased significantly, and no extraction air for airfoil cooling is needed. These changes would require moderate engineering activities to redesign and verify the modified $501 \mathrm{~F}$ compressor. The airfoil cooling medium is converted from air to recycled flue gas, and the 
combustors must be able to efficiently combust the low-thermal-value fuel gas having a supply temperature of about $595^{\circ} \mathrm{C}$. Significant equipment for recycled flue gas compression (intercooled compressor) and air-flue gas heat exchange is needed. The thermochemical recuperator is a more complex reactor than in the Steam-TCR cases, having reactor sections for partial combustion, steam and $\mathrm{CO}_{2}$ reforming and heat exchange.

Efficient cleaning of the recycle flue gas may be required to eliminate the accumulation of fuel contaminant and equipment corrosion/wear products to protect the compressor and turbine. The steam bottoming cycle and HRSG are modified substantially and the quality of high-pressure steam that can be generated is limited in the Flue Gas-TCR cycle.

The economics of the Flue Gas-TCR power plant and the conventional combustion turbine plant (both Simple-Cycle and Combined-Cycle) are compared in Table 5, showing both capital cost and cost-of-electricity. Flue Gas-TCR is not cost competitive with either the conventional Simple-Cycle or Combined-Cycle, and it is unlikely that significant cost improvements can be made through further evaluation.

Table 5. Summary of Flue Gas-TCR Results

\begin{tabular}{|c|c|c|c|c|c|}
\hline & $\begin{array}{r}\text { Capacity } \\
\text { (MWe) } \\
\end{array}$ & $\begin{array}{l}\text { Efficiency } \\
(\%, \text { LHV) }\end{array}$ & $\begin{array}{l}\text { Capital Cost } \\
(\$ / \mathrm{kW}) \\
\end{array}$ & $\begin{array}{c}\mathrm{COE} \\
\text { (cents/kWh) }\end{array}$ & $\begin{array}{c}\text { Practicality } \\
\text { Issues }\end{array}$ \\
\hline \multicolumn{6}{|l|}{ Fuel Gas-TCR } \\
\hline - Simple cycle & 181 & 38.7 & 564 & 4.8 & $\begin{array}{l}\text { - Major modification to } \\
\text { combustion turbine } \\
\text { - Combustion performance } \\
\text { - Desulfurized fuel needed } \\
\text { - Need to clean recycle flue } \\
\text { gas }\end{array}$ \\
\hline - Combined cycle & 228 & 57.1 & 660 & 3.9 & $\begin{array}{l}\text { - Major modification to } \\
\text { combustion turbine } \\
\text { - Combustion performance } \\
\text { - Need to clean recycle flue } \\
\text { gas }\end{array}$ \\
\hline $\begin{array}{l}\text { Conv. Simple- } \\
\text { Cycle }\end{array}$ & 166 & 35.7 & 276 & 4.6 & - Commercial \\
\hline $\begin{array}{l}\text { Conv. Combined- } \\
\text { Cycle }\end{array}$ & 264 & 56.8 & 410 & 3.5 & - Commercial \\
\hline
\end{tabular}

\subsection{DEVELOPMENT REQUIREMENTS}

The development requirements for the Steam-TCR power plant to reach a state of commercial readiness are:

- sub-scale experimental verification of the reformer performance and catalyst selection and optimization of properties 
- detailed cycle optimization evaluations in parallel with thermochemical recuperator design optimization

- sub-scale combustor performance verification testing with the low-thermal-value fuel gas

- component integration pilot plant testing

- demonstration plant operation

The Steam-TCR power plant does not require significant modifications to combustion turbine equipment, and the design modifications that are required can be performed with a strong background from similar turbine modifications and similar combustor modifications for other applications. A commercial background in the area of steam reforming of fuels exists that can be drawn upon to design the thermochemical recuperator and to select appropriate catalyst materials and properties. Thus, the Steam-TCR development requirements are only moderate in cost and schedule, and the technology can be considered highly feasible and practical.

Flue Gas-TCR represents a much more challenging technology to develop to a state of commercial readiness than Steam-TCR. Development requirements include:

- sub-scale experimental verification of the partial combustor/ reformer performance and catalyst selection and optimization of catalyst properties,

- sub-scale combustor performance verification testing with the very low-thermal-value fuel gas and low excess oxygen,

- identification of recycle flue gas cleaning needs, identification of cleaning techniques and sub-scale verification testing,

- design of modified air compressor and turbine integration, and verification testing,

- evaluation of flue gas airfoil cooling design and sub-scale verification testing,

- detailed cycle optimization and plant integration evaluations in parallel with thermochemical recuperator design optimization,

- component integration pilot plant testing,

- demonstration plant operation.

\subsection{TCR CONCLUSIONS}

A Steam-TCR power plant with a heavy duty industrial combustion turbine, fueled by natural gas, has the potential for cycle efficiencies significantly higher than the conventional Simple-Cycle power plant, but lower than the conventional Combined-Cycle power plant. The relatively simple equipment modifications required, the potentially improved $\mathrm{NO}_{\mathrm{x}}$ emissions that result, and the potential cost-competitiveness of the cycle make Steam-TCR a valid candidate for continued development. Its application to alternative turbine fuels having lower reforming temperatures than natural gas may be even more attractive. 
A Flue Gas-TCR power plant with a heavy duty industrial combustion turbine, fueled by natural gas, shows a small efficiency advantage over a conventional Combined Cycle. The complexity of the Flue Gas-TCR cycle, the significant equipment modifications and development effort required to utilize the cycle, its technical uncertainties, and its potentially high cost make Flue Gas-TCR questionable for continued consideration. 


\section{PARTIAL OXIDATION}

\subsection{CYCLE DESCRIPTION}

The partial oxidation (PO) of hydrocarbons is a technique used extensively in the chemical process industries to generate a wide variety of petrochemicals. It has been previously discussed in the literature as a means for improving the performance of combustion turbine power plants (Rabovitser et al, 1996).

In partial oxidation, a substoichiometric quantity of air is mixed with the turbine fuel to result in the generation of a low-thermal-value fuel gas by the following basic reactions:

\section{partial oxidation reaction}

$$
\mathrm{CH}_{4}+1 / 2 \mathrm{O}_{2}=\mathrm{CO}+2 \mathrm{H}_{2} \quad(\Delta \mathrm{H}=-44 \mathrm{~kJ} / \mathrm{mole})
$$

$\underline{\text { water-shift reaction }}$

$$
\mathrm{CO}+\mathrm{H}_{2} \mathrm{O} \Leftrightarrow \mathrm{CO}_{2}+\mathrm{H}_{2} \quad(\Delta \mathrm{H}=41 \mathrm{~kJ} / \mathrm{mole})
$$

as well as the Boudouard reaction, and direct methane decomposition (Equations 3 and 4). The formation of carbon must be minimized in the operation of the partial oxidizer to minimize equipment fouling and erosion, and to minimize carbon losses. The reactions do not require catalysis, and the fuel does not require desulfurization.

A flow sheet for the Partial Oxidation power plant is shown in Figure 4. The fuel, in this case natural gas, is partially oxidized in the partial oxidation (PO) reactor. The resulting fuel gas is expanded through the high-pressure, PO turbine. The air for partial oxidation is compressed in stages with intercooling. The air for the PO turbine may be extracted from the combustion turbine compressor or may be taken from ambient air, or a combination of the two. The high-pressure PO turbine is cooled by steam. Additional steam is also injected into the PO reactor to control the reaction temperature. The fuel gas generated in the PO reactor, after expanding through the PO turbine, is combusted and expanded in a conventional, heavy duty combustion turbine. The energy in the combustion turbine exhaust is recovered to generate steam for use in the PO turbine. There is no steam turbine in this cycle. 


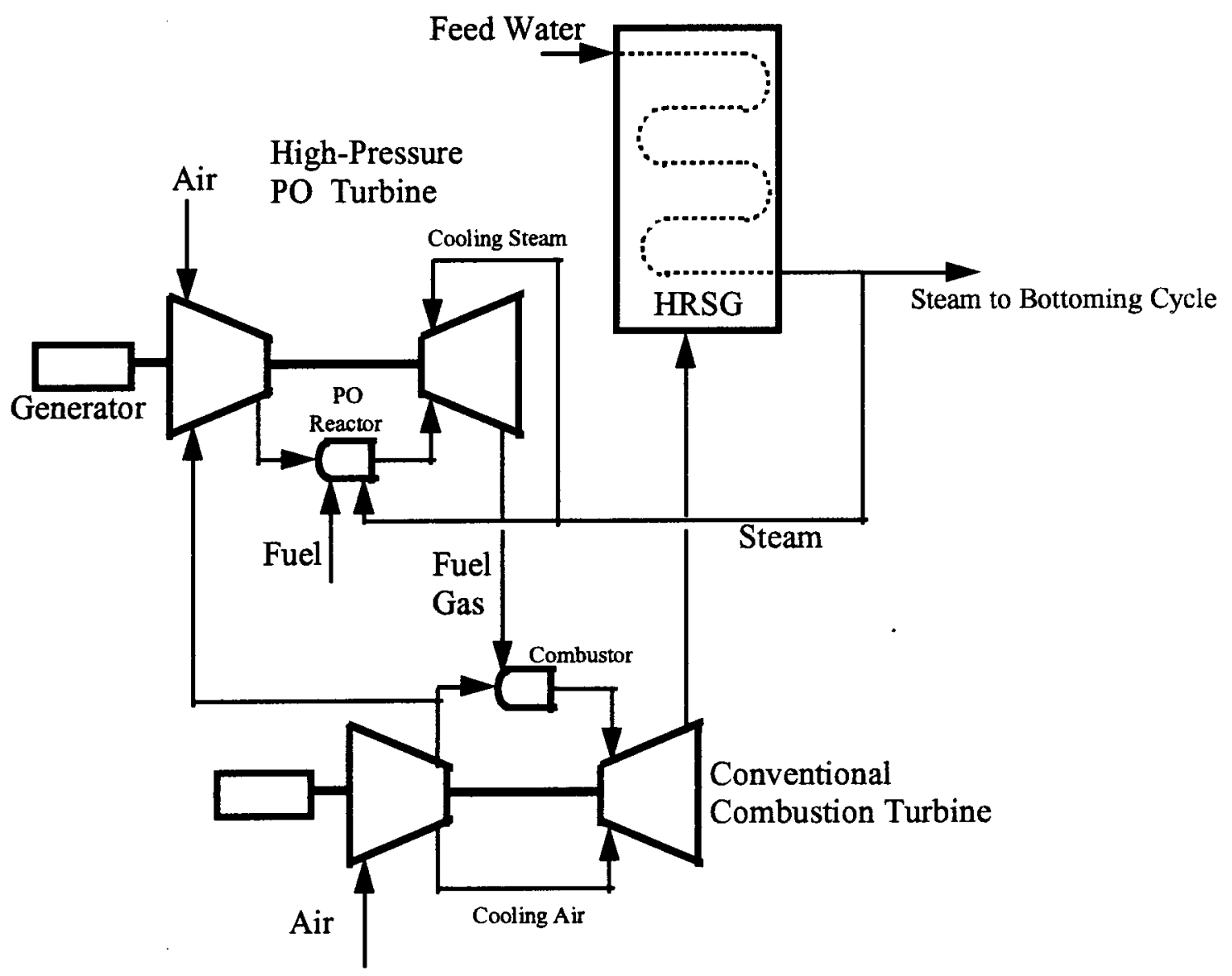

Figure 4. PO Cycle Diagram 
Partial oxidation benefits power cycles by combustion of fuels in two or more stages, providing the several potential advantages over conventional cycles: lower air consumption and reduced air compressor work; increased power plant thermal efficiency; lower $\mathrm{NO}_{\mathrm{x}}$ emissions; and, less cooling of the same gas turbine.

\subsection{EVALUATION BASIS}

The Partial Oxidation cycle has been evaluated for an actual, heavy duty industrial combustion turbine in combination with a hypothetical, high-pressure PO turbine with the following basis:

- The PO turbine is a hypothetical engine, specifically designed for the PO application

- The combustion turbine is a Westinghouse 501F

- Turbine mass flow is maintained at the 501F design mass flow

- Rotor inlet temperature is maintained at the $501 \mathrm{~F}$ design rotor inlet temperature

- Fuel: natural gas (desulfurization not required; modeled as pure methane)

- Conditions: ISO, base load

- Partial oxidation conversion performance estimated at equilibrium conversion

- Heat recovery steam generator pinch point temperature: $10^{\circ} \mathrm{C}$

- The PO air compressor took the PO reactor air from ambient.

The process flow diagrams were evaluated using the ASPEN Plus ${ }^{\mathrm{TM}}$ process simulator which is well adapted to handling power cycles with nonstandard chemical conversions. A detailed stageby-stage model of the $501 \mathrm{~F}$ was incorporated into the process simulator. A rough stage-by-stage model of the PO turbine was also utilized. Detailed designs were not conducted on the PO reactor, looking only at its thermodynamic potential and rough sizing.

The PO process and cycle conditions were not optimized in the evaluation, but acceptable conditions for the PO reactor were selected and applied and only limited cycle variations were considered. Standard assumptions used in Westinghouse commercial cycle estimates for power island component heat losses, pressure drops, mechanical losses, efficiency factors and auxiliary losses have been applied. The same economic premises applied for the TCR power plant evaluation were applied for the PO power plant economic evaluation.

\subsection{CYCLE PERFORMANCE}

A major parameter in the cycle evaluation was the PO turbine inlet pressure. Table 6 lists the performance results for the PO power plant, showing the breakdown of power generated in the PO power plant for three different PO turbine inlet pressures: $45 \mathrm{bar}, 60 \mathrm{bar}$ and $100 \mathrm{bar}$. The 
projected cycle efficiency ranges from $48.4 \%$ for a PO turbine operating pressure of 45 bar to $49.6 \%$ for an operating pressure of 100 bar. There is no steam turbine in this cycle. Additional optimization of the cycle to improve the efficiency is possible.

Table 6. Performance of the Partial Oxidation Power Plant

\begin{tabular}{|l|c|c|c|}
\hline PO Turbine Pressure (bar) & 45 & 60 & 100 \\
\hline PO Turbine Results & & & \\
\hline Shaft Power (MW) & 16.9 & 33.9 & 51.4 \\
\hline Generator Losses (kW) & 338 & 679 & 1027 \\
\hline Aux \& BOP Losses (kW) & 0 & 0 & 0 \\
\hline Net GT Power (MW) & 16.6 & 33.2 & 50.3 \\
\hline 501F Turbine Results & & & 303.8 \\
\hline Shaft Power (MW) & 303.3 & 305.6 & 3545.7 \\
\hline Generator Losses (kW) & 3545.7 & 3545.7 & 0 \\
\hline Aux \& BOP Losses (kW) & 0 & 0 & 300.3 \\
\hline Net GT Power (MW) & 299.8 & 302.0 & 50.16 \\
\hline GT Simple-Cycle Eff., \%-LHV & 49.08 & 49.94 & \\
\hline Overall Cycle Results & & & 4131 \\
\hline BOP Losses (kW) & 4131 & 4131 & 986.6 \\
\hline Water Pump (kW) & 463.5 & 635.0 & 350.1 \\
\hline Net Cycle Power (MW) & 315.6 & 334.7 & 49.7 \\
\hline Net Cycle Efficiency, \%-LHV & 48.4 & 49.3 & \\
\hline
\end{tabular}

Operating at pressures of 45 bar and 60 bar, the maximum steam generation (or energy recovery) is attained when the pinch point of $10^{\circ} \mathrm{C}$ is reached at the economizer. However, operation at a pressure of $100 \mathrm{bar}$, the controlling mechanism becomes the combustion at the $501 \mathrm{~F}$ combustor. Attempts to increase the steam generation in the boiler will result in incomplete combustion (or oxygen deficiency) at the $501 \mathrm{~F}$ combustor outlet, or will result in lower than controlled temperature at the combustor outlet. This is evident from the continuing decreases of oxygen concentration at the $501 \mathrm{~F}$ combustor outlet when the operating pressure increases from 45 bar to 100 bar. That is why the efficiency improvement is marginal, from $49.3 \%$ to $49.6 \%$, when operating pressure is increased from 60 bar to 100 bar. Substantial increase beyond an operating pressure of 60 bar is not recommended.

The PO gas turbine is a hypothetical turbine unique to each set of conditions evaluated in this analysis; i.e., operating inlet pressures at 45 bar, 60 bar, and 100 bar. In this evaluation, the energy from the intercooling of the PO turbine compressor was not recovered. The conditions of a few key streams are summarized in Table 7 for operating pressures of 60 bar, the near-optimum 
inlet pressure for the PO turbine. The composition of the low-thermal-value fuel gas issued from the PO turbine is shown in Table 7. This fuel gas has a hot thermal value (LHV) of about 2.3 $\mathrm{MJ} / \mathrm{nm}^{3}$ (63 Btu/scf). The fuel gas molecular weight is about 20.7 .

The oxygen concentration in the stack for the PO cycle is generally less than $7 \%$ compared to a value of $12.7 \%$ for the conventional Simple-Cycle. The higher the PO turbine operating

Table 7. Conditions of Selected Gas Streams - 60 Bar PO Turbine Pressure

\begin{tabular}{|c|c|c|c|c|c|}
\hline Stream & $\begin{array}{c}\text { PO Reactor } \\
\text { Outlet }\end{array}$ & $\begin{array}{c}\text { PO Turbine } \\
\text { Outlet }\end{array}$ & $\begin{array}{c}\text { Combustion } \\
\text { Turbine Outlet }\end{array}$ & Steam & Stack Gas \\
\hline Temperature ( ${ }^{\circ} \mathbf{C}$ ) & 1316 & 773 & 608 & 575 & 98 \\
\hline Pressure (bar) & 59.3 & 15.9 & 1.05 & 65.5 & 1.01 \\
\hline Mass Flow (kg/hr) & $0.56 \times 10^{6}$ & $0.81 \times 10^{6}$ & $1.77 \times 10^{6}$ & $0.33 \times 10^{5}$ & $1.77 \times 10^{6}$ \\
\hline $\begin{array}{l}\text { Composition (mole } \\
\text { fraction) }\end{array}$ & & & & & \\
\hline $\mathbf{O}_{2}$ & 0 & 0 & & & \\
\hline $\mathbf{N}_{\mathbf{2}}$ & 0.4646 & 0.3002 & 0.5421 & & 0.0574 \\
\hline $\mathbf{C O}_{\mathbf{C O}}$ & 0.0780 & 0.0504 & 0 & & 0.5426 \\
\hline $\mathbf{H}_{\mathbf{2}} \mathbf{O}$ & 0.0430 & 0.0278 & 0.0444 & & 0 \\
\hline $\mathbf{C H}_{\mathbf{4}}$ & 0.2529 & 0.5173 & 0.3498 & 1.0 & 0.0443 \\
\hline $\mathbf{H}_{\mathbf{2}}$ & 0 & 0 & 0 & & 0 \\
\hline $\mathbf{A r}$ & 0.1558 & 0.1006 & 0 & & 0 \\
\hline $\mathbf{C}$ (solid) & $1.96 \mathrm{E}-20$ & $1.27 \mathrm{E}-20$ & 0.0065 & & 0.0065 \\
\hline & & & & & 0 \\
\hline
\end{tabular}

pressure is raised, the lower the oxygen content becomes. Indeed, the total air requirement is smaller than that of a conventional Simple-Cycle, reducing air compressor power requirement significantly.

\subsection{TECHNICAL FEASIBILITY AND ECONOMICS}

The major equipment components in the PO power plant are the

- PO air compressor (intercooled)

- PO reactor

- PO turbine

- Combustion turbine

- HRSG

As individual components, all of these components are technically feasible. The components of greatest uncertainty are the PO reactor and the PO turbine. The PO reactor is a relatively 
simple device and its design can follow the extensive commercial experience with partial oxidation of hydrocarbons in the chemical process industries. One issue for the partial oxidation of natural gas is the potential formation of soot. It is estimated that under the selected conditions of operation soot formation should be minimal, but demonstration of soot-free performance over the range of power plant operating conditions would be required.

The PO turbine is a component with uncertain technical feasibility at the selected design conditions. The expansion of hot, clean flue gases in similar expander equipment has been considered in the past as being commercially viable for application in coal gasification plants, although the inlet pressure, expansion ratio, and inlet temperature $\left(80 \mathrm{bar}, 3.0,300^{\circ} \mathrm{C}\right.$, respectively) were similar, but not as challenging as the PO turbine conditions (60 bar, $3.7,760^{\circ} \mathrm{C}$, respectively) (Feerrar et al., 1978). Engineering methods are well developed that permit the airfoil cooling design using either open-loop or closed-loop steam.

The combustion turbine can be adapted to function in the PO power plant. Modifications to the combustion turbine air compressor, combustors and expander section to utilize the hot, lowthermal-value fuel gas as technically feasible using existing engineering techniques and materials. The efficient combustion of the hot, low-thermal-value fuel gas with the low excess air levels required in the PO power plant is a technical issue requiring further evaluation and testing.

The PO power plant is not unusually complex compared to commercial power plants. Integration of the PO power plant components into a reliable, controllable power plant is an area for additional evaluation, but is not a technical feasibility issue. It is expected that such integration is technically feasible based on experience with other relatively complex Combined Cycle power plants.

The PO Cycle efficiency competes with the conventional Combined-Cycle and the SimpleCycle. It is essentially a Simple-Cycle, and it may be possible to configure a Combined-Cycle version if the steam requirements for the PO reactor can be reduced. Other options are also available to improve the PO cycle efficiency, such as integrating the combustion turbine air compressor with the PO air compressor, and using the PO air compressor intercooling energy in the power cycle. Economic comparison is made in Table 8. The cost is competitive with both the conventional Simple-Cycle and Combined-Cycle, and it is expected that additional cost reductions can be identified through cycle and equipment optimizations. 


\subsection{DEVELOPMENT REQUIREMENTS}

The development requirements for the PO power plant to reach a state of commercial readiness are:

- sub-scale experimental verification of the partial oxidation reactor performance,

- detailed cycle optimization evaluations in parallel with thermochemical recuperator design optimization,

- sub-scale combustor performance verification testing with the low-thermal-value fuel gas,

- sub-scale experimental verification of the partial oxidation performance,

- sub-scale combustor performance verification testing with the very low-thermal-value fuel gas and low excess oxygen,

- detailed cycle optimization and plant integration evaluations,

- demonstration plant operation.

Table 8. Comparison of PO Power Plant Economics with Conventional Power Plants

\begin{tabular}{|l|c|c|c|c|}
\hline & $\begin{array}{c}\text { Capacity } \\
(\mathrm{MWe})\end{array}$ & $\begin{array}{c}\text { Efficiency } \\
(\%, \mathrm{LHV})\end{array}$ & $\begin{array}{c}\text { Capital } \\
\text { Cost } \\
(\$ / \mathrm{kW})\end{array}$ & $\begin{array}{c}\text { COE } \\
(\mathrm{cents} / \mathrm{kWh})\end{array}$ \\
\hline PO power plant & 335 & 49.3 & 291 & 3.6 \\
\hline $\begin{array}{l}\text { Conv. Simple- } \\
\text { Cycle plant }\end{array}$ & 166 & 35.7 & 276 & 4.6 \\
\hline $\begin{array}{l}\text { Conv. } \\
\text { Combined- } \\
\text { Cycle plant }\end{array}$ & 264 & 56.8 & 410 & 3.5 \\
\hline
\end{tabular}

\subsection{CONCLUSIONS}

The PO power plant does not require significant modifications to the combustion turbine equipment. Design modifications that are required can be performed with a strong background from similar turbine modifications and similar combustor modifications for other applications. A commercial background in the area of partial oxidation of fuels exists that can be drawn upon to design the PO reactor with soot formation being a technical concern. The development of a new, high-pressure PO turbine is required to use the cycle, and new turbine development is normally an expensive undertaking requiring several years of development time. Existing high-pressure turbines that can be modified for this application need to be identified and evaluated. Thus, the PO cycle development requirements could be extensive in cost and schedule, although the technology can be considered feasible and practical. There is ample economic potential with the PO power plant to merit continued evaluation and development. 


\section{PARTIAL OXIDATION REPOWERING}

\subsection{REPOWERING CONCEPTS}

Conventional coal-fired power plants have been repowered with natural gas-fired combustion turbines by so-called "Hot Windbox" repowering techniques that utilize the turbine exhaust gas as preheated combustion air for the coal fuel. Repowering of a conventional coal-fired power plant improves the power plant efficiency and increases the plant electrical output while maintaining the existing steam cycle equipment. Conventional coal-fired power plants could be repowered with a PO turbine that provides a low-thermal-value fuel gas to the coal-fired boiler to replace some or all of the coal fuel. The low-thermal-value fuel gas could be fired through the burners or as supplemental firing into the superheater. This concept has been previously discussed (Rabovitser et al., 1996). Firing into the superheater region could also act as reburn technology to reduce plant $\mathrm{NO}_{\mathrm{x}}$ emissions.

Figure 5 shows the conceptual process flow diagram for this PO repowering technique. The figure shows a PO reactor and PO turbine that operate to generate a low-thermal-value fuel gas that can be fired in the existing furnace. The outlet temperature of the PO reactor is controlled by adjusting steam flow generated from a heat exchanger on the boiler stack gas stream. The heat recovery exchanger also generates enough steam for cooling of PO turbine stages, since air cooling cannot be used in the PO turbine. A conceptual evaluation of the technique has been performed looking only at limited aspects of the repowering scheme.

\subsection{EVALUATION BASIS}

Repowering of a coal-fired steam turbine plant rated at $180 \mathrm{MW}$, was studied in an ASPEN process simulation. The existing steam turbine plant has a gross heat rate of $7700 \mathrm{Btu} / \mathrm{kWh}$ and a gross efficiency of $44.3 \%$. The steam conditions are $125 \mathrm{bar} / 538^{\circ} \mathrm{C} / 538^{\circ} \mathrm{C}$.

Since the gas-side operating conditions, such as gas flow rate, temperature profile, and heat transfer surfaces in superheater, repeater, evaporator, and economizer were not available, the current simulation can best be described as exploratory. For repowering, a more exact simulation is required which will include detailed calculations of heat transfer in the radiant section and along the convective sections of the heat recovery boiler to verify that the existing equipment is sufficient to generate the steam conditions and quantity required for the steam turbine. 


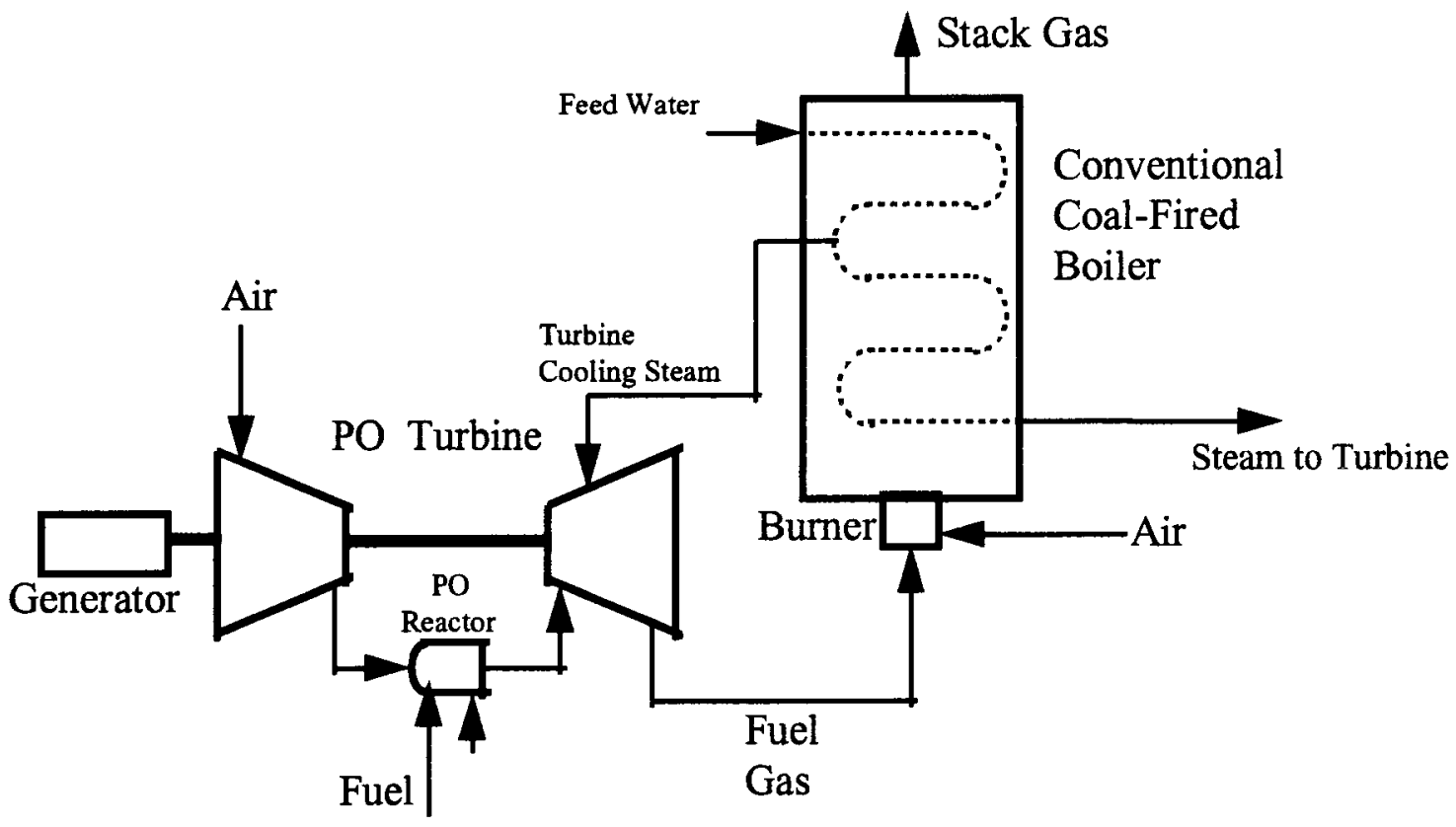

Figure 5. PO Turbine Repowering Diagram 
The PO reactor was simulated assuming equilibrium outlet compositions are achieved. No equipment of operating cost estimates were generated for the repowering scheme.

\subsection{REPOWERING PERFORMANCE}

Three PO turbine operating pressures were used in the simulation: $13.8 \mathrm{bar}, 20.7 \mathrm{bar}$, and 27.6 bar. The air supply to the PO reactor was set to be one-half of the stoichiometric requirement for complete combustion of natural gas.

The fuel gas generated through partial combustion was combusted in the radiant section of the heat recovery boiler. Staged combustion will be necessary in this case to generate high temperature required at the radiant section for efficient heat transfer. A mixed temperature of the combusted gas with an $8 \%$ excess oxygen content will give a temperature of around $1066^{\circ} \mathrm{C}$, far from the $1370^{\circ} \mathrm{C}-1650^{\circ} \mathrm{C}$ generally obtained in the radiant section of a coal-fired boiler.

The heat generated through combustion of $\mathrm{PO}$ fuel gas was then recovered by the existing heat recovery steam boiler consisting of superheater, reheater, evaporator, and economizer. Feed to the economizer is from polished condensate at $0.53 \times 10^{6} \mathrm{~kg} / \mathrm{hr}$. The superheated steam going to the steam turbine was at the rated conditions of 125 bar and $538^{\circ} \mathrm{C}$. The stream returning from the steam turbine for reheat was at 35 bar and $354^{\circ} \mathrm{C}$. The reheated steam back to the steam turbine had the conditions of 35 bar and $538^{\circ} \mathrm{C}$. The superheated and reheated steams had similar conditions and flow rates as that of the coal-fired power plant, so the existing steam turbine would function similarly and generate the rated $180 \mathrm{MW}$ of power. The existing air preheater would need to be converted to, or replaced by, a steam generator to generate steam for cooling of PO turbine stages and for mixing in the PO reactor.

The calculated combined cycle efficiency for PO turbine operating pressures of 13.8, 20.7, and 27.6 bar are $45.4 \%, 46.4 \%$, and $46.5 \%$, respectively. Increasing the operating pressure improves the cycle efficiency initially, but quickly levels off. This is because at a pressure of $13.8 \mathrm{bar}$, the pinch point (which was assumed to be $10^{\circ} \mathrm{C}$ ) was at the economizer. At higher pressures of 20.7 and 27.6 bar, the pinch point shifts to the steam generator because the steam generated would have higher temperatures due to higher steam pressures. Selected stream conditions are summarized in Table 9 for the PO turbine operating pressure of $20.7 \mathrm{bar}$. The fuel gas molecular weight is about 21.9 and the hot fuel gas thermal value (LHV) sent to the boiler is about $3 \mathrm{MJ} / \mathrm{nm}^{3}$ (85 Btu/scf). 
Table 9. Selected Stream Conditions for Operating Pressure at 20.7 bar

\begin{tabular}{|c|c|c|c|c|}
\hline Stream & $\begin{array}{c}\text { PO Reactor } \\
\text { Outlet }\end{array}$ & $\begin{array}{c}\text { PO Turbine } \\
\text { Outlet }\end{array}$ & $\begin{array}{c}\text { Combustor } \\
\text { Outlet }\end{array}$ & $\begin{array}{c}\text { Stack } \\
\text { Gas }\end{array}$ \\
\hline Temperature $\left({ }^{\circ} \mathrm{C}\right)$ & 1316 & 608 & 1038 & 124 \\
\hline Pressure, bar & 20.7 & 1.1 & 1.06 & 1.05 \\
\hline $\begin{array}{c}\text { Mass Flow } \\
(\mathrm{kg} / \mathrm{hr})\end{array}$ & $0.49 \times 10^{6}$ & $0.50 \times 10^{6}$ & $1.37 \times 10^{6}$ & $1.37 \times 10^{6}$ \\
\hline \multicolumn{5}{|l|}{$\begin{array}{c}\text { Composition } \\
\text { (mole fraction) }\end{array}$} \\
\hline $\mathrm{O}_{2}$ & 0 & 0 & 0.0794 & 0.0794 \\
\hline $\mathbf{N}_{2}$ & 0.4625 & 0.4505 & 0.6802 & 0.6802 \\
\hline $\mathrm{CO}$ & 0.0831 & 0.0809 & 0 & 0 \\
\hline $\mathrm{CO}_{2}$ & 0.0413 & 0.0402 & 0.0519 & 0.0519 \\
\hline $\mathrm{H}_{2} \mathrm{O}$ & 0.2421 & 0.2618 & 0.1804 & 0.1804 \\
\hline $\mathrm{CH}_{4}$ & trace & trace & 0 & 0 \\
\hline $\mathbf{H}_{2}$ & 0.1654 & 0.1611 & 0 & 0 \\
\hline $\mathbf{A r}$ & 0.0055 & 0.0054 & 0.0081 & 0.0081 \\
\hline C (solid) & $2.30 \mathrm{E}-20$ & $2.24 \mathrm{E}-20$ & 0 & 0 \\
\hline
\end{tabular}

The boiler gross power output results are:

Base steam turbine: $181 \mathrm{MWe}$

13.8 bar PO turbine: $269 \mathrm{MWe}$

20.7 bar PO turbine: $286 \mathrm{MWe}$

27.6 bar PO turbine: $298 \mathrm{MWe}$

The PO turbine repowering scheme can increase the power plant output and plant thermal

efficiency significantly, and the PO turbine can be designed and operated at pressures in the same range as current heavy duty combustion turbines.

\subsection{TECHNICAL FEASIBILITY AND DEVELOPMENT REQUIREMENTS}

The technical feasibility and development requirements of the PO equipment (primarily the PO reactor and PO turbine) for repowering is similar to the technical feasibility of the same components in the PO power plant scheme of Section 4. The larger issue is the feasibility of effectively repowering an existing coal-fired boiler so that the steam generation rate and steam quality is maintained at the steam turbine design conditions. Full replacement of coal by PO fuel gas may not be possible without extensive modification to the boiler heat transfer surface and boiler flow passages. Partial replacement of coal by PO fuel gas is expected to be more potentially feasible scheme, but the extend of coal replacement that can be economically achieved will be specific to each individual power plant design. 


\subsection{REPOWERING CONCLUSIONS}

PO repowering of conventional coal-fired boilers shows some potential for improving plant efficiency and increasing power output, as well as improving the stack emissions of sulfur oxides and $\mathrm{NO}_{\mathrm{x}}$. Partial replacement of coal is a more feasible option than full replacement of coal. Additional repowering evaluations are needed that consider the details of some specific coal-fired power plant repowerings. Such evaluations should assess the furnace and boiler retrofit modifications needed and estimate the retrofit costs in order to develop a quantitative understanding of the merits of this repowering scheme with respect to conventional hot windbox repowering. 


\section{CONCLUSIONS AND RECOMMENDATIONS}

The performance potential, the cost potential and the feasibility issues for the TCR and PO power plants are summarized in Tables 10 and 11. Comparison is made to the conventional Simple-Cycle and Combined-Cycle power plants.

Table 10. Summary of TCR Results

\begin{tabular}{|c|c|c|c|c|c|}
\hline & $\begin{array}{l}\text { Capacity } \\
\text { (MWe) }\end{array}$ & $\begin{array}{l}\text { Efficiency } \\
(\%, \text { LHV) }\end{array}$ & $\begin{array}{l}\text { Capital } \\
\text { Cost } \\
(\$ / \mathrm{kW})\end{array}$ & $\begin{array}{c}\mathrm{COE} \\
\text { (cents/kWh) }\end{array}$ & $\begin{array}{l}\text { Feasibility } \\
\text { Issues }\end{array}$ \\
\hline Steam-TCR & 216 & 48.9 & 339 & 3.7 & $\begin{array}{l}\text { - Large water consumption } \\
\text { - Desulfurized fuel needed } \\
\text { - TCR vessel design }\end{array}$ \\
\hline \multicolumn{6}{|l|}{ Fuel Gas-TCR } \\
\hline - Simple Cycle & 181 & 38.7 & 564 & 4.8 & $\begin{array}{l}\text { - Major modifications to } \\
\text { combustion turbine } \\
\text { - Combustion performance } \\
\text { - Desulfurized fuel needed } \\
\text { - Need to clean recycle flue } \\
\text { gas } \\
\text { - Complex cycle } \\
\end{array}$ \\
\hline - Combined Cycle & 228 & 57.1 & 660 & 3.9 & $\begin{array}{l}\text { - Major modification to } \\
\text { combustion turbine } \\
\text { - Combustion performance } \\
\text { - Desulfurized fuel needed } \\
\text { - Need to clean recycle flue } \\
\text { gas } \\
\text { - Complex cycle }\end{array}$ \\
\hline $\begin{array}{l}\text { Conv. Simple } \\
\text { Cycle }\end{array}$ & 166 & 35.7 & 276 & 4.6 & - Commercial \\
\hline $\begin{array}{l}\text { Conv. Combined } \\
\text { Cycle }\end{array}$ & 264 & 56.8 & 410 & 3.5 & - Commercial \\
\hline
\end{tabular}

Table 11. Summary of PO Results

\begin{tabular}{|l|c|c|c|c|l|}
\hline & $\begin{array}{c}\text { Capacity } \\
(\mathrm{MWe})\end{array}$ & $\begin{array}{c}\text { Efficiency } \\
(\%, \mathrm{LHV})\end{array}$ & $\begin{array}{c}\text { Capital } \\
\text { Cost } \\
(\$ / \mathrm{kW})\end{array}$ & $\begin{array}{c}\text { COE } \\
(\text { cents/kWh) }\end{array}$ & \multicolumn{1}{|c|}{$\begin{array}{c}\text { Feasibility } \\
\text { Issues }\end{array}$} \\
\hline $\begin{array}{l}\text { Simple Cycle } \\
\text { PO }\end{array}$ & 335 & 49.3 & 291 & 3.6 & $\begin{array}{l}\bullet \text { Large water consumption } \\
\text { - Soot formation } \\
- \text { PO turbine development } \\
\bullet \text { Combustion performance }\end{array}$ \\
\hline $\begin{array}{l}\text { Conv. Simple- } \\
\text { Cycle }\end{array}$ & 166 & 35.7 & 276 & 4.6 & $\bullet$ Commercial \\
\hline $\begin{array}{l}\text { Conv. Combined- } \\
\text { Cycle }\end{array}$ & 264 & 56.8 & 410 & 3.5 & $\bullet$ Commercial \\
\hline
\end{tabular}


Compared to conventional combustion turbine power cycles, the TCR power cycles show the potential for significant plant heat rate improvements, but their general feasibility is at issue. The Steam-TCR scheme, the simplest and cheapest of the TCR cycles, has the highest potential feasibility. Steam-TCR has estimated power plant efficiencies significantly higher than the conventional Simple-Cycle power plant, and is also cost competitive. On-the-other-hand, SteamTCR has efficiency lower than can be achieved with the conventional Combined-Cycle, but is still cost competitive with the conventional Combined-Cycle. High consumption of demineralized water may be an issue for Steam-TCR at some locations. It is recommended that Steam-TCR be evaluated further with the goal of optimizing the cycle and the major equipment designs.

Flue Gas-TCR power plant efficiencies are estimated to be only slightly greater than the efficiency of conventional Combined-Cycle power plants. The complexity of the Flue Gas-TCR power plant is judged to be high. Extensive modifications are required to the combustion turbine and to other conventional power plant components. The development requirements for the Flue Gas-TCR power plant are great, with combustion performance and recycle flue gas cleaning requirements being key technology issues. Cost estimates indicate that there is little incentive to continue the evaluation of Flue Gas-TCR or to consider development of the technology.

PO shows potential for significant performance improvements compared to conventional Simple-Cycles, having efficiency significantly higher than the Simple-Cycle, but not as great as the conventional Combined-Cycle. The PO power plant also has the potential to produce much more power than the conventional Simple-Cycle and Combined-Cycle power plants, but with several technical issues. Soot formation is a major technical issue. The development of the high-pressure PO turbine is a major development requirement. The efficiency of the PO power plant is estimated to be slightly greater than that of the Steam-TCR power plant, and the PO power plant has relatively large consumption of demineralized water, although less than Steam-TCR. The economic potential of the PO power plant is very good with the estimated costs being competitive with both the conventional Simple-Cycle and Combined-Cycle. It is recommended that the $P O$ cycle be evaluated further with the goal of optimizing the cycle and the major equipment designs.

The PO conventional coal-fired boiler repowering scheme shows some interesting possibilities as a partial-coal-replacement repowering technique. The conventional steam power plant efficiency can be increased significantly and its power output increased moderately with the PO repowering scheme. The scheme is probably more suited to partial replacement of coal than it 
is to complete coal replacement, and it may be applied to reduce power plant emissions of sulfur and $\mathrm{NO}_{\mathbf{x}}$. The evaluation performed here was only a preliminary consideration of the repowering performance, and further evaluation to consider the practical aspects and performance of the boiler repowering adaptation to the $P O$ fuel gas is needed.

Significant effort remains to develop, verify and commercialize both Steam-TCR and PO for combustion turbine power systems. It is evident that some alternative fuel types, especially those having lower reforming temperatures, may be utilized in the Steam-TCR cycle more efficiently than can natural gas. Also, combustion turbines more advanced than the reference $501 F$ used in this evaluation, such as the $501 G$ and ATS, will probably have greater efficiency and cost benefits from these advanced cycles than does the $501 F$. 


\section{REFERENCES}

Bannister, R. L. et al, 1995, "Development Requirements for an Advanced Gas Turbine System," ASME Journal of Engineering for Gas Turbines and Power, Vol. 117, pp. 724-733.

Briesch, M. S. et al, 1995, "A Combined Cycle Designed to Achieve Greater Than 60 Percent Efficiency," ASME Journal of Engineering for Gas Turbines and Power, Vol. 117, pp. 734-741.

Feerrar, S, et al, Fluor Engineers and Constructors, Inc., "Effects of Sulfur Emission Controls on the Cost of Gasification Combined Cycle Power Systems," EPRI AF-916, October 1978.

Harvey, S. P., K. F. Knche, H. J. Richter, January 1995, "Reduction of Combustion Irreversibility in a gas Turbine Power Plant Through Off-Gas Recycling," Transactions of the ASME, Vol. 117, p. 24.

Horner, M. W., and W. R. Hines, July 1992, Chemically Recuperated Gas Turbine, US Patent $5,133,180$

Janes, J. et al., January 1990, Chemically Recuperated Gas Turbine, California Energy Commission.

Kesser, K. F. et al., 1994, "Analysis of a Basic Chemically Recuperated Gas Turbine Power Plant," ASME Journal Engineering for Gas Turbines and Power, Vol. 116, p. 277

Ottarsson, Kari, June 1991, "Comparison of a Combined Cycle with a Chemically Recuperated Cycle,” LUTMDN-TMVK--5204-1-49-91.

Rabovitser, J. K. et al., 1996, "Evaluation of Thermochemical Recuperation and Partial Oxidation Concepts for Natural Gas-Fired Advanced Turbine Systems," ASME Paper 96-GT-290.

Rao, A. et al., August 1993, Evaluation of Advanced Gas Turbine Cycles, Final Report to Gas Research Institute, GRI-93/0250.

Rostrup-Nielsen, J. R. et al., October 1995, Chemical Recuperation and Gas Turbines, Presented at the EPRI Conf. on New Power Generation Technologies, San Francisco, CA.

Scalzo, A. J. et al., 1996, Evaluation of Westinghouse Heavy-Duty Power Generation and Industrial Combustion Turbines, ASME Journal of Engineering for Gas Turbines and Power, Vol. 118, pp. 316-330.

Vakil, H. B., 1983, Thermodynamic. Analysis of Gas Turbine Cycles with Chemical Reactions, American Chemical Society, 0097-6156/83/0235

Walters, A. B., W. H. Weber, October 1995, Power Generation Applications of Reformed Methane with Carbon Dioxide, Presented at the EPRI Conf. on New Power Generation Technologies, San Francisco, CA. 